\title{
Relevansi Konsep Nilai Petatah Petitih Sunan Gunung Djati dalam Pendidikan Islam
}

\author{
Hanif Cahyo Adi Kistoro, Aminah Nur Latifa Sibarani \\ Universitas Ahmad Dahlan Yogyakarta, Indonesia \\ Jl. Ringroad Selatan, Kragilan, Tamanan, Kec. Banguntapan, Bantul, Yogyakarta 55191 \\ Email: hanif.kistoro@pai.uad.ac.id
}

\begin{abstract}
This study aims to explain the relevance of the concept of petatah petitih/ Sunan Gunung Jati advice with the values of Islamic education. This type of research is library research (library research). The primary data sources of this research are inscriptions, books, journals, and other works. Secondary sources were obtained from informants through interviews-data analysis techniques using content analysis techniques by doing source criticism, interpretation, and historiography. From the results of the study, it was concluded that the method of Sunan Gunung Jati in religious education through the concept of petatah-petitih. The relevance of petitah petatih with Islamic culture is the balance of the value of monotheism and humanity (tajug and poor poor), prayer is the pillar of religion (yen prayer pucuke arrow refuge, fasting educates to be patient, honest and controlling lust (yen fasting and tetaling gundewa refugee), consistent in worship (fixed kang worship), fear of the prohibition of God (Wedi ing Allah), give thanks for the favors given (Manah den thank God and God), and always ask for forgiveness (Kudu ngakehaken repentance).
\end{abstract}

Keywords: Relevance, Petatah-Petitih Concept Sunan Gunung Jati, Islamic Education

\begin{abstract}
Abstrak: Penelitian ini bertujuan untuk menjelaskan relevansi konsep petatah petitih/nasehat Sunan Gunung Jati dengan nilai-nilai pendidikan islam. Jenis penelitian ini adalah penelitian kepustakaan (library research). Sumber data utama dari penelitian ini adalah prasasti, buku, jurnal dan karya lainnya. Sumber sekunder didapatkan dari informan melalui wawancara. Teknik Analisis data menggunakan teknik analisis konten (content analysis) dengan melakukan kritik sumber, interpretasi dan histroriografi. Dari hasil penelitian, ditarik kesimpulan bahwa metode Sunan Gunung Jati dalam pendidikan agama melalui konsep petatah-petitih. Relevansi petatah petitih dengan pendidikan islam adalah adanya keseimbangan nilai Tauhid dan kemanusiaan (tajug dan fakir miskin), shalat adalah tiang agama (yen sembahyang kungsi pucuke panah, puasa mendidik untuk sabar, jujur dan mengendalikan hawa nafsu (yen puasa den kungsi tetaling gundewa), konsisten dalam ibadah (Ibadah kang tetap), takut larangan Allah (Wedi ing Allah), mensyukuri nikmat yang diberikan (Manah den syukur lan Allah), dan selalu meminta ampunan (Kudu ngakehaken pertobat).
\end{abstract}

Kata Kunci: Relevansi, Konsep Petatah-Petitih Sunan Gunung jati, Pendidikan Islam 


\section{PENDAHULUAN}

Sesuatu yang berharga biasanya bernilai. Dalam ilmu pengetahuan khususnya ilmu pendidikan, nilai mempunyai peran yang penting. Nilai merupakan suatu komponen keyakinan ataupun perasaan yang menjadi suatu identitas yang memberikan pengaruh tertentu dalam berpikir, berperasaan dan berperilaku (Daradjat, 1992: 260). Nilai inilah yang diharapkan menjadi hasil dari proses pendidikan. Seseorang yang mendapatkan pendidikan akan mempunyai nilai yang lebih baik dari segi pengetahuan (knowledge), keterampilan (skill), sikap/perilaku (attitude). Nilai melekat dalam perilaku sehingga tidak dapat disentuh dengan pancaindra. Oleh karenanya nilai merupakan sesutu yang ideal dan abstrak. Ada beberapa pengertian tentang nilai menurut para ahli. Nilai merupakan rangkaian dalam keyakinan yang memberikan sesuatu yang berharga dalam pemikiran dan tindakan (Abu Ahmadi dan Noor Salimi, 2008:202). Pengertian lain menjelaskan segala sesuatu mempunyai batasan. Nilai adalah ukuran dari sesuatu yang adadi jagat raya (Azizi, 2009:15).

Dari pengertian tersebut, nilai mengandung sesuatu yang berharga yang dihasilkan dari pemikiran dan menjadi sebuah kesepakatan dimasyarakat dalam menjaga tingkah laku manusia.

Ada dua sumber utama nilai dalam kehidupan manusia yaitu sumber ilahiah dan sumber insaniah. Nilai ilahiah merupakan nilai yang berasal dari Tuhan dan diajarakan lewat Utusan-Nya. Keimanan, ketakwaan, kemaslahatan dan bentuk lainnya adalah bukti sifat yang bernilai. Pada nilai ini tugas manusia adalah menginterpretasikan nilai tersebut salah satunya dalam bentuk perilaku yang baik.

Nilai insaniah merupakan kesepakatan manusia yang di gunakan untuk kehidupan bermasyarakat dan pengembangan peradaban manusia. Nilai sosial, nilai budaya, nilai ilmu pengetahuan merupakan contoh nilai insaniah yang sifatnya dinamis.

Pendidikan yang dianggap sebagai proses penanaman nilai-nilai tentu mempunyai kompleksitas persoalan didalamnya. Tugas pendidikan adalah selalu mencari dan menggali makna nilai untuk di terapkan dalam kehidupan manusia.

Pendidikan adalah suatu usaha manusia untuk membina kepribadiannya sesuai dengan nilai yang berlaku dimasyarakat. Proses Pendidikan bahkan juga terjadi dalam lingkup masyarakat yang sederhana sekalipun (Ramayulis, 2008:166).

Esensi pendidikan adalah seperangkat bimbingan dan pengarahan dalam kehidupan manusia yang berbentuk kemampuan dasar dan kemampuan ajar yang merubah kepribadiannya sebagai makhluk sosial (Arifin,1994:14).

Pendidikan dengan kata lain merupakan upaya pendidik utuk menjadikan anak didik menjadi dewasa. Indikator kedewasaan adalah kemampuan anak didik menetapkan pilihan dan mempertanggungjawabkan perbuatan secara mandiri. Apabila ini terwujud maka pendidikan dianggap berhasil (Kistoro, 2014:10).

Islam adalah agama yang menganjurkan pentingnya pendidikan. Islam mengajarkan tentang kehidupan dunia dan akhirat. Bentuk nyata islam dalam dunia pendidikan adalah kewajiban pemeluknya untuk belajar dan melaksanakan pendidikan. Mulai dari lahir hingga akhir hayat.

Asas dan filsafat pendidikan islam dapat di lihat dalam kandungan Al-quran seperti dalam surat Al-Nahl ayat 89:
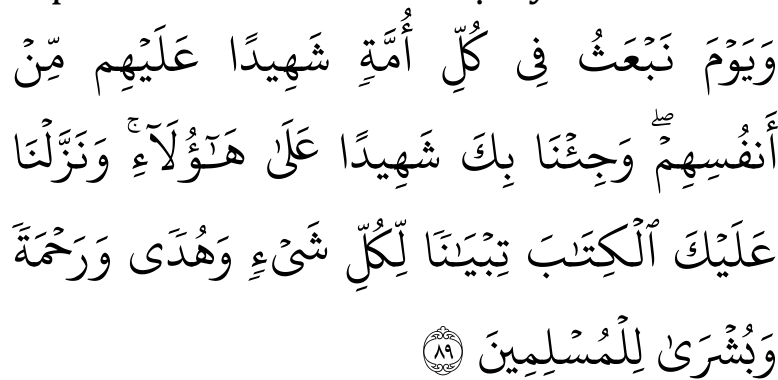
"(Dan ingatlah) akan hari (ketika) Kami bangkitkan pada tiap-tiap umat seorang saksi atas mereka dari mereka sendiri dan Kami datangkan kamu (Muhammad) menjadi saksi atas seluruh umat manusia. Dan Kami turunkan kepadamu Al Kitab (Al Quran) untuk menjelaskan segala sesuatu dan petunjuk serta rahmat dan kabar gembira bagi orang-orang yang berserah diri".

Sesuai dengan Qs. An Nahl diatas ada salah satu kata kunci yang cukup jelas bahwa Al Quran yang dalam ayat ini disebut sebagai Al kitab diturunkan untuk menjelaskan segala sesuatu yang ada didunia. Selain itu juga sebagai petunjuk bagi yang mau mempelajarinya.

Jadi dapat disimpulkan dari semuanya bahwa pengertian secara umum tentang nilai dalam pendidikan Islam adalah seperangkat prinsip hidup dan keyakinan yang saling berhubungan yang memuat ajaran agama untuk mengajarkan dan memberdayakan serta mengembangkan kemampuan manusia dalam mencapi manusia seutuhnya sesuai dengan kodrat penciptaanya yaitu menjadi hamba dan khalifah di muka bumi.

Sesuai sejarahnya, ajaran Islam di Nusantara mulai muncul dan berkembang tidak terlepas dari peranan sembilan orang wali yang disebut Walisongo. Wali artinya penghulu agama dan Songo berasal dari bahasa Jawa yang artinya sembilan. Jadi, Walisongo berarti sembilan orang wali Allah SWT. yang menyebarkan agama Islam. Salah satu tokoh yang termasuk dalam anggota walisongo adalah Syarif Hidayatullah atau biasa disebut sebagai sebutan Sunan Gunung Jati.

Syarif Hidayatullah merupakan salah satu wali yang diberikan amanah untuk menyebarkan ajaran Islam di pulau Jawa khususnya jawa barat. Syarif Hidayatullah atau Sunan Gunung Jati mengabdikan seluruh kehidupan untuk menyebarkan ajaran dengan proses yang panjang dan tidak mudah. Salah satu ciri pendidikan yang islam yang di ajarkan oleh Sunan Gunung Jati adalah adanya pondok pesantren di wilayah Cirebon dan Sekitarnya (Kurnia, 2007 : 2)

Kesuksesan Sunan Gunung Jati dalam menyebarkan ajaran Islam dapat ditunjukkan dari beberapa peninggalan baik dalam aspek sosial, sosial, seni dan pendidikan. Dampak dari dakwah sunan gunung jati juga membawa pengaruh positif dalam kehidupan masyarakat Cirebon dan sekitarnya (Hardi dan Rohman, 2014 : 1)

Salah satu konsep nilai yang sangat cocok dengan pendidikan adalah petatahpetitih. Konsep petatah petitih ini sampai sekarang masih menjadi nilai yang dianut masyarakat khususnya didaerah Cirebon (Wildan, 2012:244).

Petatah-petitih adalah ungkapan luhur yang dijadikan pedoman dalam kehidupan berbangsa, bermasyarakat dan beragama khususnya bagi umat Islam di Cirebon. Ajaran Petatah-petitih yang dibawa oleh Sunan Gunung Jati sebagai bekal agar bisa meningkatkan keimanan (Tauhid) Manusia dengan Allah SWT. Salah satu Efek dari keimanan adalah munculnya perilaku yang baik dalam bentuk hubungan harmonis antar sesama manusia (muamalah).

Nilai-nilai dalam pendidikan dapat digolongkan dalam empat aspek, antara lain:petatah-petitih yang berkaitan dengan ketakwaan dan keimanan (Tauhid), petatah-petitih yang berkaitan dengan kedisiplinan, petatah-petitih yang menyangkut kearifan dan kebijaksanaan, petatah-petitih tentang kesopanan dan tatakrama (adab) (Eman Suryaman, 2015:131).

Ajaran keimanan dan ketakwaan yang terdapat dipetatah-petitih yang ditinggalkan oleh Sunan Gunung Jati tidak hanya berada pada tataran pengakuan lisan, tetapi didasari makrifat terhadap Allah dan dipraktikkan dalam amal perbuatan (Eman Suryaman, 2015:131).

Dalam petatah-petitih keimanan dan ketakwaan ada tujuh pokok ajaran yang diwariskan oleh Sunan Gunung Jati lebih menekankan pada hubungan manusia dengan Allah yang dibina melalui ibadah, 
antara lain aku Sunan Gunung Jati titip tajug dan fakir miskin, apabila menjalankan shalat harus khusyuk, jika puasa harus kuat seperti anak panah, istiqomah dalam ibadah, takut dan bersyukur kepada Allah, dan banyak bertobat (Wildan, 2002: 29).

Penjelasan sederhana dari konsep diatas bahwa sebagai manusia bermasyarakat perlu membantu orang yang tidak punya dan kesusahan. Pendidikan agama diharapkan mengajarkan anak didik untuk peka dan peduli terhadap sesama. Sifat tolong dan saling berbagi merupakan salah satu wujud pendidikan karakter.

Begitu pula dalam beribadah, diharapkan selalu khusyu' dan istiqomah. Konsistensi dalam ibadah akan menelurkan nilai-nilai kebaikan seperti kedisiplinan, keteraturan dan lainnya.

Penekanan nilai-nilai lainya adalah memperbanyak syukur atas segala apa yang sudah diberikan. Kenikmatan karunia yang selalu disyukuri akan mengarahkan manusia untuk merasa cukup dan tidak berlebih. Rasa syukur ini dapat mencegah tumbuhnya sifat tamak. Bukti konkrit yang dapat dilihat di jaman sekarang adalah perilaku korupsi karena berkurangnya rasa syukur. Ingin mendapatkan sesuatu yang banyak dengan menghalalkan caranya.

Tujuan pengajaran atau pendidikan berdasarkan nilai-nilai ajaran islam ini adalah untuk membentuk moralitas atau akhlak yang menjadi bekal mencapai kebahagiaan abadi yang tidak bisa dijelaskan secara materi dan kata-kata, atau kebahagiaan yang lebih bersifat ukhrawi.

Petatah petitih yang diajarkan Sunan Gunung Jati memandang bahwa seluruh aktivitas ibadah dapat bernilai sebagai upaya pendekatan diri kepada Allah dan semuanya perlu proses pembelajran. Orang tidak akan tiba-tiba mampu melaksanakan sesuatu tanpa mempelajari terlebih dahulu. Diharapkan dengan orang belajar memahami ajaran agama dengan benar, maka akan selalu mengamalkan ajaran agamanya dengan baik. Perilaku seseorang dapat menjadi cermin bagaimana kemampuan memahami ajaran agamanya.

Dengan kata lain, adanya nilai-nilai dalam konsep petatah petitih ini dapat di jadikan bahan dalam proses pendidikan agama terutama pendidikan karakter anak didik.

\section{KONSEP TEORI \\ Biografi Sunan Gunung Jati}

Sunan Gunung Jati dilahirkan di Mesir pada 1448 M dengan nama Syarif Hidayat atau Syarif Hidayatullah (Atja, 1986:36). Ia lahir di tengah-tengah keluarga yang sangat religius dan terhormat. Ayah beliau merupakan keturunan raja Mesir yang bernama Syarif Abdullah dengan gelar Sultan Mahmud, sedangkan ibunya yang bernama Nyai Rara Santang juga seorang keturunan "darah biru" karena ia adalah putri Prabu Siliwangi, raja Pajajaran (Sunardjo, 1983:43).

Sunan Gunung Jati berasal dari campuran keturunan Arab dan Indonesia asli. Dari garis keturunan ibunya, Sunan Gunung Jati adalah cucu Prabu Siliwangi dari dari kerajaan Pajajaran. Darah Nabi Muhammad S.A.W. mengalir dari ayahnya, syarif Abdullah. Sunan Gunung Jati atau Syarif Hidayatullah merupakan keturunan ke-22 Rasulullah (P.S. Sulendraningrat, 1978:15).

Sunan Gunung Jati dalam menempuh pendidikan tidak melalui lembaga formal seperti yang berlaku sekarang. Akan tetapi, bentuk pendidikan yang ditempuhnya adalah dengan melakukan pengembaraan fisik, intelektual, dan spiritual. Tidak jarang beliau berpindah dari satu guru ke gurunya yang lain, dan juga ia juga berpidah ke dari satu tempat ke tempat lain untuk belajar. Hal ini dilakukan agar ilmu Islam yang didapatkan semakin banyak, di samping itu didorong oleh keinginannya yang sangat besar menjadi guru agama Islam (Suryaman, 2015:27). 
Keinginannya untuk mendalami ilmu agama Islam sebetulnya telah terlihat semenjak ia beranjak remaja. Ia sangat gemar membaca berbagai macam kitab. Saat usia 20 tahun, meminta izin kepada ibunya untuk pergi ke Makkah guna mempelajari ilmu agama Islam. Melihat tekadnya yang kuat, sang ibu mengizinkannya untuk mewujudkan citacitanya (Suryaman, 2015:28).

Pendidikan beliau dimulai dari kota Makkah dengan belajar kepada ulama besar Yekh Tajuddin Al Qurtubi tentang dasar-dasar Islam. Guru yang kedua adalah Syek Athailah Syadzili yang merupakan ulama ilmu tassawuf.

Dalam menimba ilmu, Syarif Hidayat telah banyak menerima nama sebagai penghargaan dari para gurunya atas kepintarannya. Ia juga diberi nama Sayid al-Kamil dan Syaikh Ibrahim Ibn Maulana Sultanil Mahmud al-Khibti. Sementara itu, pamannya yang memegang jabatan sementara sebagai ganti ayahnya yang telah wafat, memberinya nama Nurdin. Sebagai anak pertama dari Sultan Mahmud, ia berhak untuk menggantikan kedudukan ayahnya. Oleh sebab itu, sesampainya beliau di Mesir, pamannya ingin menyerahkan kedudukan tersebut kepadanya. Akan tetapi, tawaran ditolak oleh Syarif Hidayat, karena pengembaraannya untuk mencari ilmu pengetahuan, di samping cita-citanya untuk menjadi seorang pengajar agama, jauh lebih menarik baginya daripada jabatan tersebut. Akhirnya, jabatan itu diserahkan kepada adiknya yang bergelar Sultan Syarif Nurullah (Sunardjo,1983:51)

Pencarian ilmu yang dilakukan syarif hidayat di lanjutkan ke tanah Jawa dengan singgah terlebih dahulu ke Gujarat (India) selama tiga bulan. Selanjutnya beliau menuju pasai untuk belajar kepada Sayid Ishak yang masih terhitung kerabatnya.

Setelah belajar pada Sayid Ishak selama dua tahun, Syarif Hidayat kembali melanjutkan perjalanannya menuju Pulau Jawa melalui Banten. Penduduk Banten pada waktu itu sudah mulai mengenal Islam berjasa Raden Rahmat atau Sayid
Rahmat dari Ampel Gading yang digelari Sunan Ampel. Dari Banten, ia melanjutkan perjalanannya menuju Ampel dengan menaiki perahu (Ekadjati,1974:130). Di Ampel kemudian Syarif Hidayat bergabung dengan Ulama lain yang kemudian terkenal dengan sebutan Walisongo.

\section{Menjadi Guru Agama}

Kedatangan Syarif Hidayat yang ditugaskan untuk menjadi guru agama khususnya di wilayah Cirebon disambut gembira oleh Haji Abdullah Iman salah satu ulama yang ada di daerah Jawa Barat. Pertemuan antara Syarif Hidayat dengan Haji Abdullah Iman pada masa itu tidak hanya untuk sekedar melepas rindu. Akan tetapi, mereka juga membahas hal-hal yang dianggap penting dan mendesak untuk dilakukan dalam rangka mengajarkan Islam kepada masyarakat (suryaman,2015:28).

Pada tahun pertamanya di Cirebon, Syarif Hidayat menjalankan tugas dakwahnya sebagai guru agama. Hal ini juga sesuai dengan keputusannya musyawarah Dewan Wali yang menugaskan beliau untuk menjadi guru agama di Cirebon menggantikan Syaikh Datuk Kahfi.

Mengawali tugasnya sebagai guru agama, Syarif Hidayat memilih Gunung Sembung sebagai basisnya, dan daerah ini termasuk wilayah Pasambangan. Syarif Hidayat juga mendirikan pesantren di sana. Daerah ini memang agak jauh dari istana milik pamannya. Namun dari sini, Syarif Hidayat mulai dapat berbaur dan menyesuaikan diri dengan budaya dan nilai-nilai yang ada di masyarakat Cirebon yang baru dikenalnya. Kondisi ini membuatnya merasa nyaman dan tidak menganggap dirinya sebagai orang asing di sana.

Dari dukuh Sembung, Syarif Hidayat memperluas wilayah dakwahnya ke daerah Babadan yang jaraknya sekitar tiga kilometer ke arah barat dari Pasambangan. Di Babadan, Syarif Hidayat atau Sunan Gunung Jati berhasil 
mengislamkan Ki Gedheng Babadan dan menikah dengan putrinya, yaitu Nyai Mas Babadan. Namun Sunan Gunung Jati menikah dengan Nyai Mas Babadan tidak memiliki putra karena Nyai Mas Babadan meninggal terlebih dahulu. Setelah lama menduda, Sunan Gunung Jati menikah lagi dengan Dewi Pakung Wati, putri Haji Abdullah Iman.

Namun tidak diperoleh keterangan berapa orang anak dari pernikahan ini. Selanjutnya, Syarif Hidayat melanjutkan tugasnya sebagai guru agama di daerah Kuwunganten, dan berhasil mengislamkan Adipati Kuwunganten bersama pengikutnya (Prawiraredja,2005:27).

Sewaktu Syarif Hidayat berdakwah di Pasambanngan, ia didatangi oleh utusan dari Banten. Utusan itu datang untuk memohon kesediaan Syarif Hidayat menjadi guru agama Islam di sana. Setelah berunding dengan Pangeran Cakrabuana, Syarif Hidayat berangkat ke Banten dengan diikuti oleh beberapa orang muridnya yang telah dewasa. Muridmurid sengaja diikutkan agar dapat membantunya dalam mengajarkan ilmu agama Islam di Banten (Suryaman, 2015:47).

Ada kemungkinan besar sebelum beliau diutus ke Banten, nama Sarif Hidayat sudah terkenal sampai ke Banten, terutama melalui pedagang-pedagang yang datang dari Banten ke Muara Jati yang pada waktu itu merupakan tempat pelabuhan yang sangat ramai disinggahi oleh para pedagang dari daerah lain. Kegiatan dakwah yang dilakukan Syarif Hidayat di Banten tidak menghadapi kesulitan yang berarti. Sebagai seorang guru agama, di samping menguasai ilmu keislaman, Syarif Hidayat juga dibekali dengan berbagai macam pengalaman dan metode yang diperolehnya dari negerinegeri Islam lainnya ketika melakukan pengembaraan untuk memperdalam ilmu keislaman. Berbekal pengalaman dan metode tersebut, Syarif Hidayat berhasil dalam menjalankan tugas dakwahnya kepada masyarakat di sana.
Keberhasilan dakwah Syarif Hidayat di Banten tidak terlepas dari hubungan baiknya dengan penguasa setempat yang telah dirintis sebelum ia menjadi guru agama di Banten. Sebagaimana dijelaskan di atas, sebelum sampai di Cirebon dari Samudera Pasai, ia sempat singgah di Banten

Dengan adanya hubungan baik antara Adipati Kuwunganten dan pengikutnya yang memeluk Islam dengan Syarif Hidayat, maka ia menikahkan adik perempuannya yang bernama Nyai Kuwunganten dengan Syarif Hidayat. Dari pernikahan ini, lahirlah dua orang anak, yang pertama adalah seorang perempuan yang bernama Ratu Winaon dan yang kedua adalah laki-laki yang diberi nama Pangeran Sabakingking (wildan, 2002:287).

Pada zaman sejarah Banten hanya disebutkan Syarif Hidayatullah melakukan dakwah di daerah Wahanten (Banten), kemudian tugas dakwahnya tersebut dilanjutkan oleh putranya, yaitu Pangeran Sabakingking atau Maulana Hasanuddin. Sementara itu, dalam sejarah Banyumas disebutkan bahwa ada seorang ulama sakti dari Gunung Srandil yang memperkenalkan ajaran Islam kepada masyarakat Kuwunganten dan pada saat itu menikah dengan putri penguasa setempat.

Setelah berhasil mengislamkan Adipati Kuwunganten dan pengikutpengikutnya, Syarif Hidayat kembali ke Cirebon pada kira-kira tahun 1479. Sesampai di Cirebon, Syarif Hidayat diserahi tugas oleh pamannya, Pangeran Cakrabuana atau Haji Abdullah, memegang jabatan sebagai Tumenggung Negeri Cirebon dengan gelar Susuhunan Jati.

Keputusan tersebut mendapatkan dukungan para wali dan lengitimasi dari Sulatan Demak. Pengangkatan ini juga mendapat dukungan dari sebagian masyarakat dan penguasa di daerah pantai utara Jawa. Kedudukannya sebagai Tumenggung juga mendapat pengakuan dari penguasa Pajajaran, yang bahkan 
menganugerahinya gelar dengan sebutan Suunan Jati Purbawisesa

Tentang keluarga Sunan Gunung Jati, diperoleh keterangan bahwa beliau mempunyai enam orang istri dan tujuh orang anak. Istri-istri Sunan Gunung Jati adalah sebagai berikut Nyai Babadan (putri Ki Gedheng Babadan), Nyai Pakungwati (putri Pangeran Cakrabuana), Nyai Kuwunganten (adik Adipati Banten), Ong Tien (seorang putri Cina), Nyai Lara Bagdad, Nyai Tepasari (putri Ki Gedheng Tepasari) dari Majapahit.

Keenam istri Sunan Gunung Jati itu tidak dinikahi dalam waktu yang bersamaan, karena ada di antara istriistrinya yang lebih dahulu meninggal dunia. Yang paling unik dari pernikahan Sunan Gunung Jati itu adalah kedudukan putri Ong Tien dari Cina yang dikenalnya saat melakukan muhibah ke negeri Tirai Bambu tersebut

Adapun putra-putri Sunan Gunung Jati adalah Ratu Winaon, Pangeran Sabakingking atau Pangeran Hasanuddin, Pangeran Jaya Kelana, Pangeran Brata Kelana, Nyai Ratu Ayu, dan Pangeran Muhammad Arifin yang biasa disebut juga Pangeran Pasarean.

Pernikahan Sunan Gunung Jati dengan keenam istrinya tidak semuanya memiliki anak. Pernikahan dengan istri pertama tidak memiliki anak dikarenakan istrinya itu meninggal dunia sebelum memiliki keturunan. Pernikahan keduanya tidak diberi keterangan berapa anak yang dimiliki oleh istri kedua Sunan Gunung Jati. Dengan istri ketiga, yaitu putri Cina, mempunyai anak, tetapi meninggal sewaktu masih kecil. Putra-putri Sunan Gunung Jati berasal dari istri ketiga, kelima, dan keenam, yang masing-masing istrinya melahirkan dua orang putra. Nyai Kuwunganten berputrakan Ratu Winaon dan Pangeran Sabakingking. Ratu Winaon menikah dengan Pangeran Raja Laut. Sementara itu, Pangeran Sabakingking menjadi penguasa Banten pada tahun 1552 dengan gelar Sultan Hasanuddin (Suryaman, 2015:30).
Kemudian Sunan Gunung Jati menikahi Nyai Lara Bagdad atau Syarifah Bagdad, putri dari Abdurahman alBaghdadi atau yang dikenal dengan Pangeran Panjunan. Dari perkawinan ini, mereka memperoleh dua orang anak, yaitu Jaya Kelana dan Brata Kelana yang dikenal sebagai Pangeran Gung Anom. Pangeran Jaya Kelana menikah dengan Nyai Pembaya, dan Pangeran Gung Anom menikah dengan Ratu Nyawa. Keduanya merupakan putri Raden Patah.

Sunan Gunung Jati wafat di usia 120 tahun (1448-1568). Dimakamkan di Giri Nur Cipta Rengga (kompleks Astana Gunung Sembung, yang berjarak lima kilometer arah utara kota Cirebon), setelah membangun dan mengembangkan kerajaan Cirebon selama delapan puluh sembilan tahun (Masduqi, 2011:14).

Setelah sunan Gunung Jati wafat, kesultanan Cirebon dilanjutkan oleh keturunannya. Banyak peninggalan Sunan Gunung Jati yang masih terjaga sampai saat ini. Secara fisik bentuk bangunan kerajaan, prasasti, dan karya tulisan masih ada. Adanya hubungan erat dengan kerajaan Banten juga menjadi bukti peninggalan sunan gunung jati. Selain peninggalan seni dan lainnya.

Gambar 1. Makam Sunan Gunung Jati

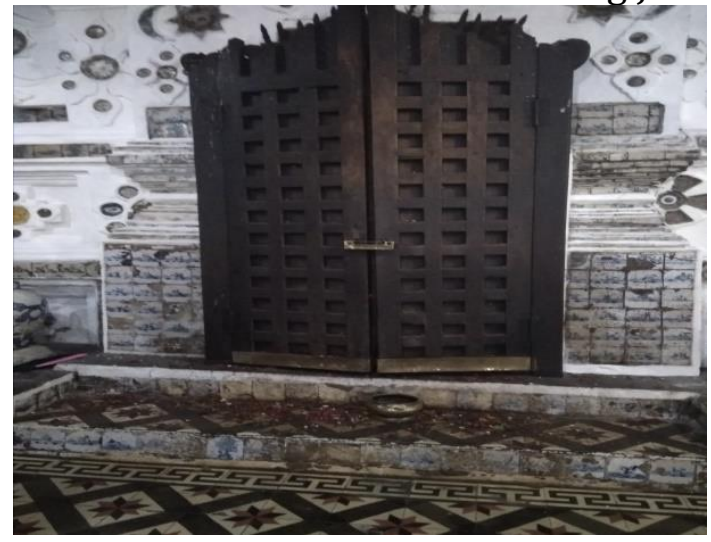

\section{Konsep Pendidikan Agama Sunan Gunung Jati}

Proses pengislaman tanah sunda oleh sunan gunung jati tidak terlepas dari beberapa metode pendekatan yang dilakukan, diantaranya: Metode mau'izhah hasanah. Metode ini dipakai untuk menghadapi tokoh-tokoh khusus atau 
orang terpandang di tengah-tengah masyarakat, seperti bupati, adipati, raja dan bangsawan. Para tokoh tersebut diperlakukan secara khusus dan istimewa yang terkadang terjadi pertemuan secara pribadi atau melalui surat yang berisi keterangan dan pemahaman tentang ajaran Islam.

Selain mengirimkan surat, para wali juga menyampaikan pesan dakwanya melalui secara lembut, saling bertukar pikiran dari hati ke hati dengan penuh perhormatan dan sikap toleransi yang tinggi terhadap pendirian dan kepercayaan tokoh-tokoh masyarakat yang bersangkutan.

Metode al-hikmah. Metode ini sangat melekat pada para wali termasuk Sunan Gunung Jati. Melalui metode kearifan ini, ajaran-ajaran Islam disampaikan baik secara populer, atraktif maupun mempunyai daya tarik kebaruan. Metode ini ditempuh terutama untuk menghadapi masyarakat awam. Dengan sangat bijaksana, masyarakat awam didekati dengan bahasa komunikasi yang baik, dan terkadang di luar kebiasaan masyarakat setempat sehingga menimbulkan ketertarikan. Selain oleh Sunan Gunung Jati, metode ini pernah dipakai juga oleh Sunan Kalijaga. Dengan hikmah dan kebijaksanaan, para wali mampu berdakah dengan menggunakan kultur lokal yang dimodifikasi secara Islam. Dengan strategi ini, masyarakat tidak merasa asing terhadap apa yang disampaikan, di samping pesan-pesan yang disampaikan juga sangat mudah diterima

Metode tadarruj atau tarbiyatul ummah. Metode ini digunakan untuk mengklasifikasikan garapan dakwah, peta dakwah yang disesuaikan dengan faktor pendidikan, serta lingkungan dan budaya agar dakwah Islam mudah dimengerti oleh umat. Dengan demikian, ajaran Islam menjadi ajaran yang cocok untuk setiap kultur zaman dan waktu (li kulli zaman wa makan). Dengan memperhatikan setiap jenjang bakat dan kecenderungan audiens, dakwah jadi mudah diterima. Untuk merealisasikan metode dakwahnya, para walisanga juga membuat kurikulum pengajaran terutama untuk lingkungan lembaga-lembaga pendidikan seperti pesantren.

Metode kaderisasi. Metode ini dimulai dengan membentuk kader-kader dakwah yang kemudian dikirim ke daerah yang memang belum tersentuh oleh ajaran Islam. Metode kaderisasi ini sangat efektif terutama untuk menyentuh daerah-daerah pedalaman yang memang belum mengenal ajaran Islam sama sekali.

Metode syura (musyawarah). Metode ini merupakan sarana untuk curah pendapat para wali dalam mengevaluasi kegiatan dakwah yang dilakukan. Dalam musyawarah ini, tidak hanya dibahas masalah umat semata, namun terkadang juga masalah mistik atau tawasuf yang memang merupakan "makanan" para wali dalam rangka pendekatan diri Allah supaya diberi bimbingan dalam menjalankan tugas dakwah (Saksono, 1995:23).

Salah satu bentuk Media dakwah kultural yang dilakukan Sunan Gunung Jati adalah melalui kesenian. Masyarakat yang menggemari wayang, tari, dan gamelan disyaratkan membayar dengan membaca syahadat untuk melihat pagelaran pertunjukan. Prosesi ini kemudian berkembang dengan sebutan Sekaten. Adanya gamelan sekaten sampai saat ini maish digelar di Keraton Kasepuhan.

Berdasarkan uraian diatas dapat dipahami bahwa konsep pendidikan agama yang dilakukan sunan gunung jati menggunakan banyak cara untuk menarik minat dan mudah dilakukan oleh masyarakat. Media seni baik tari, wayang dan seni lainnya menjadi jalan dalam mengajarkan islam di tanah Sunda.

Tidak hanya kesenian, dalam kegiatan Ibadah, Sunan Gunung Jati juga mengajarkan empat tingkatan ibadah yaitu syariat, tarekat, hakikat, ma'rifat. Ajaran ini dibungkusdalam bentuk kesenian agar mudah merasuk di masyarakat. Syariat disimbolkan dengan wayang sebagai perwujudan manusia 
sebagai hamba, sedangkan dengan balong, hakikat disimbolkan dengan topeng, dan makrifat disimbolkan dengan ronggeng (wildan, 2001:307)

Hakikat yang disimbolkan dengan topeng adalah sesuatu yang tersembunyi. Seorang manusia akan mampu memperolehnya kalau ia mematuhi dalangnya dalam meniti tarekat. Jika seseorang sampai pada hakikat yang tersembunyi, ia akan menemukan keindahannya, yaitu makrifat. Simbolsimbol ini mengisyaratkan bahwa perjalanan hidup manusia di dunia tidak terlepas dari skenario Yang Mahakuasa, sehingga ketika memiliki kekuasaan atau kekayaan jangan disombongkan.

Simbol-simbol yang terdapat diatas sering dimuculkan dalam upacara-upacara slametan dan sedekahan, yang pada bulan tertentu menjadi tradisi. Selain itu perayaan tradisi keislaman yang berasal dari ajaran Wali Songo, seperti upacara sakatenan yang dilaksanakan untuk memperingati kelahiran Nabi Muhammad SAW juga di gelar. Tradisi ini biasanya dilangsungkan hampir di seluruh kerajaan Islam yang ada di Jawa. Barzanji dan sedekah sultan atau dikenal dengan grebeg, yaitu membagi-bagikan makanan sebagai hadiah dari sultan kepada rakyatnya. Di Cirebon kegiatan ini biasanya dipusarkan di Masjid Agung Sang Ciptarasa (Saksono, 1995:150).

Adapun fungsi dari upacara ini adalah memberikan ketenangan batin dan kestabilan emosi serta kesehatan jasmani bagi rakyatnya oleh penguasa. Slametan bagi masyarakat Jawa berfungsi sebagai wahana untuk ketenangan batin. Dalam upacara slametan biasanya ada sejenis makanan yang dibuat dari beras ketan tang dilumat pada suatu talam besar sehingga membentuk sebuah piring yang tipis.

\section{Nilai-nilai Pendidikan Islam dalam Petatah Petitih Sunan Gunung Jati}

Ajaran sunan Gunung Jati secara khusus lebih mengutamakan pendidikan karakter dan kepribadian. Dalam bahasa agama sisebut pendidikan Aqidah dan Akhlak. Salah satu yang sampai saat in masih menjadi tema pendidikan di masyarakat Cirebon adalah konsep Petatah petitih. Petatah Petitih merupakan sebuah ajaran yang berbentuk kata-kata kiasan tertentu yang mempunyai mendalam berdasarkan ajaran Islam. Petatah-petitih ini mengandung makna ajaran hidup berupa pandangan hidup, ajuran, pesan, teguran, nasihat dan lain sebagainya. Petatah-petitih tersebut mengajarkan berbagai hal, seperti ketakwaan, akhlak yang baik, kedisplinan, dan lain-lain (Arif, 2013:399).

Keimanan atau Tauhid merupakan hal yang prinsip bagi seorang pemimpin. Pemimpin yang tidak memiliki iman akan mudah tergerus oleh perubahan dan kemegahan yang materi. Keimanan akan menjadikan seorang pemimpin lebih arif, bijaksana, serta mempunyai tanggung jawab sosial dan tanggung jawab kepada Tuhan. Keimanan juga akan melahirkan tata nilai Rabbaniyah, yaitu sebuah tatanan nilai yang didasarkan pada kesadaran hidup bahwa semuanya berasal dari Tuhan dan kembali kepada-Nya.

Pepatah-petitih Sunan Gunung Jati yang berkaitan dengan masalah keimanan, diantaranya: Insun titip tajug lan fakir miskin. Pengertiannya, Sunan Gunung Jati sangat berharap untuk bahwa tajug dan Fakir miskin di jaga. Kandungan makna dan isi yaitu Sunan Gunung Jati tidak mewariskan harta dan tahta, tetapi tajug (mushalla) dan fakir miskin. Tajug merupakan simbol nilai pendidikan Islam antara nilai dunia dan akhirat.

Prinsip ini mengandung makna bahwa harkat dan martabat manusia adalah sama. Tidak seorang pun di antara manusia yang berhak merendahkan harkat dan martabat orang lain, apalagi menguasainya. Manusia adalah sama di sisi Tuhan. Setiap manusia memiliki hak asasi untuk hidup dengan harkat yang mulia (Nawawi,1992:155).

Kata tajug disini fungsinya bukan hanya sebagai tempat sholat, tapi disitu juga ada nilai pendidikan Islam. Dimana 
pendidikan agama dilakukan di tajugtajug setelah sholat maghrib sampai jam 9. Dan ini menjadi garis kalau Ingsun titip tajug Ian fakir miskin itu adalah istilah dari pendidikan.

Ingsun titip tajug mengandung makna pendidikan agama supaya manusia harus belajar wudhu, belajar shalat, belajar berdoa, dan belajar Al-Qur'an dan sebagainya. Sedangkan titip fakir miskin juga mengandung makna pendidikan Islam yaitu supaya kita yang hidupnya berkecukupan bisa menyantuni fakir miskin. Mau mempunyai kepekaan terhadap lingkungan sosial sebagai salah satu bentuk pendidikan karakter.

Nilai-nilai pendidikan Islam yang terdapat dalam petatah-petitih Ingsun titip tajug Ian fakir miskin adalah tentang nilai ke-Tuhanan atau Tauhid nilai akhlak/moral, nilai ketawadukan, nilai kesamaan derajat, nilai keseimbangan dan nilai ketakwaan. Nilai-nilai tersebut adalah bagian dari ajaran islam.

Dalam kontek agama nilai religiusitas yang terkandung dalam petatah petitih Ingsun titip tajug lan fakir miskin merupakan bagian dari pengajaran Sunan Gunung Jati dalam menyampaikan nilai-nilai keislaman yang luhur dengan mengggunakan bahasa yang sangat sederhana. Penggunaan kata tajug sebagai simbol dari agama dan fakir miskin mewakili simbol kesosialan, Sunan Gunung Jati dalam menyampaikan makna kandungan dalam Al-Qu'ran untuk beriman dan melakukan amal saleh.

Nilai Etika, Pesan Ingsun titip tajug lan fakir miskin yang disampaikan oleh Sunan Gunung Jati mengandung nilai-nilai yang berkaitan dengan etika, baik etika kepada Allah maupun etika sesama manusia. Sebagai makhluk yang diciptakan, tugas manusia adalah menjadi Hamba dan menjadi khalifah/pemimpin. Fungsi keduanya membutuhkan etika dalam pelaksanaannya.

Pesan Sunan Gunung jati dalam menitipkan tajug dan fakir miskin sebagai simbol dan aspek keagamaan dan kesosialan ini mengajarkan agar dalam kehidupan sehari-hari bisa menerapkan nilai-nilai yang berlandasan keseimbangan atau dalam Islam lebih dikenal dengan istilah tawazun. Bentuk dari keseimbangan yang dimaksud adalah berkaitan dengan hablumminallah dan hablumminannas, yang nantinya bisa berimplikasi kepada orientasi manusia dalam menjalani kehidupannya.

Etika terhadap Allah, Tajug merupakan simbol dari hubungan makhluk dengan khaliq atau hablumminallah. Bentuk yang paling umum dan mudah untuk dipahami dalam beretika atau berakhlak kepada Allah adalah dengan menaati segala perintahnya dan menjauhi semua larangannya. Pun pada tajug yang merupakan simbol keagamaan, maka keberadaannya perlu diberdayakan sebagai alat dalam mendekatkan diri kepada Allah SWT.

Selain akhlak kepada Allah, ada etika terhadap sesama yang ditunjukkan dengan membantu kepada fakir miskin sebagai bentuk simpati dan empati. Sikap simpati disini wujudkan dengan cara tidak segan dalam memberikan bantuan dan pertolongan bagi mereka yang kurang mampu, terlebih golongan fakir miskin. Sedangkan sikap empati, ibadah puasa bisa dijadikan latihan untuk ikut merasakan kehidupan fakir miskin yang serba kekurangan sehingga nantinya akan muncul sikap kepedulian dan bertanggung jawab.

Gambar 2. Prasasti Ingsun titip tajug Ian

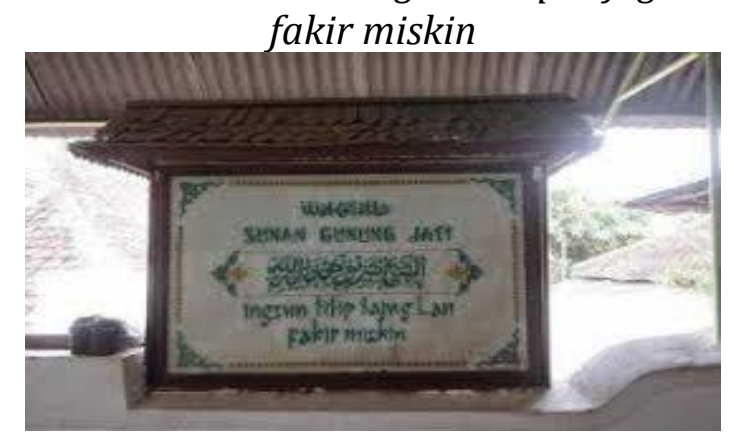

Petatah Petitih kedua tentang ketauhidan adalah Yen sembahyang kungsi tertaling gundewa. Penegrtian disini adalah apabila shalat, harus khusyuk dan tawadhu' seperti anak panah yang 
menancap kuat. Shalat merupakan salah satu rukun diantara lima rukun Islam (Zurinal dan Amirudin, 2008:64), yaitu mengucap kalimat dua syahadat, shalat, puasa, zakat dan haji bila mampu. Kelima rukun itu merupakan kewajiban setiap muslim untuk melaksanakannya, baik laki-laki atau perempuan yang sudah dewasa dan berakal sehat atau mukalaf. Shalat merupakan ibadah kepada Allah yang rukun, syarat, bacaan dan gerakan diatur secara khusus, Diawali dari gerakan takbir dan diakhiri dengan salam. Ibadah shalat merupakan amalan yang akan ditanya nantinya dihari kiamat. Karena shalat tingkat ketakwaan dan bisa mendekatkan diri kepada Allah SWT.

Shalat punya nilai filosofi yang sangat dalam bagi umat Islam. Kebenaran bukan sesuatu yang mudah diperoleh, sehingga setiap saat harus dimohonkan kepada Tuhan. Maksudnya dari ini adalah manusia harus mempunyai sikap rendah hati. Shalat sebetulnya adalah mendidik untuk bersikap rendah hati dengan inti ihdina ash-shirath al-mustaqim. Jika seseorang memohon petunjuk kepada Allah, ia harus membersihkan diri dari pengakuan kalau ia sudah tahu.

Sikap rendah hati adalah suatu sifat yang mutlak dimiliki oleh setiap orang islam, tiadanya rasa rendah hati akan membuat seseorang merasa benar sendiri, tidak mau mendengarkan pendapat orang lain, dan cenderung bersikap otoriter terhadap orang yang di bawahnya. Jika sikap keangkuhan yang tidak mau mendengarkan dimiliki oleh pemimpin, maka negara akan menyengsarakan rakyat yang dipimpinnya

Dengan demikian, shalat yang khusyuk dan tawaduk itu adalah seperti anak panah, pesan dari beliau, yang akan mendidik kita sikap tawaduk dan rendah hati, yang mau menerima apapun itu masukan dari orang lain.

Petatah petitih Yen puasa den kungsi tetaling gandewa dianalogkan seperti tali anak panah yang kuat. Puasa, selain mempunyai nilai kesalehan individu, juga mempunyai nilai sosial. Orang yang berpuasa akan bisa merasakan bagaimana penderitaan yang dirasakan oleh orang yang secara ekonomi tidak mencukupi (Suryaman, 2015: 106).

Bagi Sunan Gunung Jati, puasa mempunyai makna yang jauh lebih dalam dari pengertian yang biasa, kuat seperti anak panah mengandung pengertian mampu menembus alam surgawi melalui ketajaman batin yang dimiliki dan dapat merasakan kehadiran Tuhan yang sangat dekat dengan dirinya (Madjid, 2003: 204).

Puasa adalah suatu ibadah khusus kepada Allah SWT dengan tujuan untuk menahan diri dari segala keinginan nafsu syahwat, nafsu perut, dan segala sesuatu yang masuk kedalam tubuh melalui kerongkongan, baik itu berupa makanan maupun minuman, obat dan sejenisnya. Waktu puasa sudah ditentukan dari terbit fajar hingga terbenamnya matahari. Puasa dilakukan dengan niat oleh umat Islam yang sudah cukup umur, berakal, tidak sedang datang bulan/ haid, tidak nifas .

Nilai pendidikan Islam yang bisa peneliti dapatkan dari yen puasa den kungsi tetaling gundewa yaitu dengan puasa dapat mendidik manusia menjadi pribadi muslim yang bertaqwa, dengan adanya puasa dapat menjadi sarana pendidikan akhlak maksud dari sarana pendidikan akhlak disini yaitu mendidik manusia untuk berkikap jujur dan amanah, bisa mendidik manusia untuk bisa hidup sederhana, bisa bersifat sabar dan bisa mengendalikan hawa nafsu (Ramayulis, 2015:166).

Petatah petitih, Ibadah kang tetap (ibadah harus terus-menerus). Kehidupan adalah suatu misteri yang harus dipecahkan oleh manusia. Ibadah sebagai satu cara mendekatkan diri kepada Allah SWT untuk memecahkan persoalan yang dihadapi. Tidak ada satupun manusia di dunia ini yang luput dari persoalan. Ketegaran dalam menghadapi dan memecahkan persoalan membutuhkan kestabilan batin. Ibadah merupakan cara kita mendekatkan diri kepada Allah dan untuk membuat batin manusia menjadi stabil. Sunan Gunung Jati menekankan 
agar selalu konsisten dalam beribadah. Orang yang konsisten dalam beribadah akan mempunyai pendirian yang kokoh.

Sikap keteguhan pendirian yang dimiliki Sunan Gunung Jati ini terlihat ketika ia diangkat sebagai pemimpin Cirebon mengantikan pamannya. Untuk ukuran pemimpin yang baru diangkat, ia termasuk yang paling berani dalam mengambil keputusan.

Petatah petitih, Wedi ing Allah (takutlah kepada Allah). Sikap ini, menurut Sunan Gunung Jati, merupakan sikap penting dan mutlak dimiliki setiap orang. Orang yang tidak takut kepada Allah akan mudah melakukan tindakantindakan melanggar hukum, baik hukum masyarakat maupun hukum agama.

Ketakutan terhadap Allah sebetulnya merupakan pembebasan manusia dari rasa kekhawatiran dan ketakutan terhadap sesama manusia. Pengalaman telah menunjukkan, jika pemimpin negara tidak mempunyai rasa takut kepada Allah, ia akan takut terhadap manusia

Rasa takut kepada Allah sebetulnya merupakan pembebasan supaya manusia tidak takut dan bergantung kepada manusia. Sikap tidak takut kepada manusia ini akan melahirkan manusia yang independen, bukan individual tetapi menghargai manusia sesuai dengan kadar kemanusiaannya.

Petatah petitih, Manah den syukur lan Allah mempunyai pengertian hati harus bersyukur pada Allah. Syukur berarti menerima segala nikmat Allah SWT yang dikaruniakan padanya. Syukur yang paling sederhana adalah cara menyebut nikmat tersebut dengan bacaan hamdallah. Bentuk lain syukur adalah dengan cara mempergunakan segala nikmat yang diperoleh baik harta benda, ilmu dan lainnya di jalan yang dikehendaki oleh Allah SWT (Husna, 2013:110).

Jadi syukur adalah salah satu bentuk penerimaan nikmat yang diperoleh dari Allah SWT. Menurut bagi Sunan Gunung Jati bentuk syukur tidak hanya terbatas pada syukur secara lisan. Akan tetapi, manusia harus bersyukur melalui sikap batin, yaitu bersyukur kepada Allah. Hati yang bersyukur akan melahirkan sifat tawaduk, menyadari kemampuan dan juga kelemahan serta keterbatasanketerbatasan yang dimilikinya sebagai manusia.

Sikap Sunan Gunung Jati yang penuh kelembutan, cinta, dan kasih sayang layaknya seorang bapak yang mengayomi anaknya mempercepatnya perkembangan ajaran Islam pada masyarakat Cirebon. Pada khususnya, masyarakat Sunda, pada umumnya

Dulunya Sunan Gunung Jati yang dianggap musuh oleh rakyat, setelah melihat sikap beliau yang penuh cinta dan kelembutan hati, mereka semua berbalik menjadi pengikut setianya.

Petatah petith Kudu ngahekaken pertobat berarti memperbanyak taubat. Taubat diartikan sebagai sebuah penyesalan terhadap kesalahan dan dosayang telah dilakukan. Tiga syarat dalam melakukan taubat adalah menyadari kesalahan, berusaha membebaskan dari jerat dosa tersebut dan bertekat untuk tidak mengulangi. Taubat adalah meninggalkan dosa yang selama ini sudah diperbuat karena Allah Swt, dengan perasaan menyesal, atas perbuatan maksiat yang selama ini diperbuat bertekad kuat untuk tidak mengulanginya dan selalu menaati perintah-Nya (Al Jauziyah, 1998: 35).

Sebagai layaknya kehidupan waliyullah, Sunan Gunung Jati selalu bertobat kepada Allah bukan saja atas dosa-dosanya yang besar, melainkan juga atas hal-hal yang bersifat Syubhat. Dengan tobat hatinya selalu dibimbing oleh Allah dalam menjalankan tugas kekhalifahan untuk memanifestasikan kebesaran dan kemahakuasaan Tuhan di bumi.

Ajaran-ajaran Sunan Gunung Jati tentang keimana dan ketakwaan pada prinsipnya adalah untuk mendidik orangorang sesudahnya untuk membawa diri dan menyadarkan kita, setiap gerak gerik yang dilakukan akan dipertanggung jawab di hari akhirat. 


\section{METODE PENELITIAN}

Riset Kepustakan adalah penelitian yang dilakukan dengan mengumpulkan sumber dari buku, majalah, atau sumber data lainnya dan menghimpun data lain dari berbagai literatur (Mahmud, 2011: 31).

Berdasarkan pengertian di atas, penelitian kepustakaan bukan hanya yang berkaitan dengan pengumpulan literatur yang ada tetapi juga berhubungan dengan teknik analisis data sesuai dengan tahaptahap penelitian.

Sumber data dalam penelitian ini diperoleh berdasarkan 2 sumber yaitu data primer dan sekunder. Sumber primer merupakan kesaksian seorang dengan mata kepala sendiri atau kesaksian dengan panca indra lain (Azwar, 2001: 5). Sumber utama yang dalam peneitian ini disebut informan adalah juru kunci di pesanggrahan Makam Sunan Gunung Jati yang berjumlah dua orang. Sumber sekunder adalah sesuatu yang diperoleh dari sumber buku-buku yang merupakan hasil penelitian ataupun catatan-catatan khusus (Gottschalk, 1986:98).

Dalam teknik pengumpulan data, peneliti menggunakan metode observasi dengan cara mengamati obyek baik secara langsung maupun tidak langsung (Riskina Ratna Ningtias, 2015). Wawancara dilakukan dalam rangka mendapatkan data berupa hasil pemikiran, alasan, keinginan, perasaan dan lainnya (Prasetyo Irawan, dkk, 2009: 81). Sementara dokumentasi dipakai untuk data yang berupa catatan peristiwa yang sudah terjadi dalam bentuk tulisan, gambaran atau karya-karya monumental dari seseorang (Sugiyono, 2012:329).

Teknik analisis data menggunakan analisis konten dengan tahapan Verifikasi data. Verifikasi dilakukan untuk mengetahui keabsahan data. Dalam menunjang keabsahan data, peneliti menggunakan teknik tringulasi data berdasarkan sumber data yaitu informan atau partisipan. Hasil dari tema-tema utama yang nantinya dirangkai menjadi sebuah penafsiran, akan di cocokkan kembali kepada informan untuk mencari kesamaan makna. Apabila masih ada yang kurang maka, peneliti mencari data tambahan dari informan untuk kejelasan data.

Interpretasi sebagai bagian tahapan berikutnya meruapakan kegiatan penafsiran fakta-fakta yang ada sehingga ditemukan struktur logisnya kemudian dirangkai agar memiliki bentuk dan struktur (Hamid dan Saleh, 2011). Tahap terakhir adalah Penulisan (Historigrafi) dimana, peneliti melakukan rekonstruksi imajinatif masa lampau manusia berdasarkan data dan bukti yang diperoleh melalui proses pengujian secara rekaman dan peninggalan masa lampau (Sjamsuddin, 2012:104).

\section{HASIL DAN PEMBAHASAN}

Proses pendidikan di wilayah jawa barat khususnya Cirebon tidak terlepas dari proses masuknya islam dalam kegiatan perdagangan. Tidak dapat disangkal lagi bahwa Cirebon merupakan pangkalan penting dalam jalur perdagangan dan pelayaran antar bangsa (Zuhdi, 1997: 4). Pada awalnya kerajaan Pajajaran mempunyai aturan ketat dengan melarang pedagang Islam masuk ke wilayah Cirebon. Kebijakan berbeda ketika Sunan Gunung Jati tiba di Cirebon. Kondisi masyarakat secara bertahap berubah dengan nuansa keislaman yang kental setelah lahirnya Kesultanan Cirebon. Pengaruh Sunan Gunung Jati sebagai penyiar agama Islam tentu memiliki peranan besar dalam pengislaman Cirebon.

Kesuksesan Sunan Gunung Jati dalam mengislamkan Tanah Sunda tentu tidak terlepas dari metode yang juga digunakan oleh para wali di Jawa Timur dan Jawa Tengah. Dengan adanya pertemuan rutin dari para wali songo, muncul pemikiran dan cara-cara yang disesuaikan dengan kondisi masyarakat, tidak terkecuali cirebon (Dadan Wildan, 2012:244).

Adanya kondisi yang demikian memerlukan metode dalam penyebaran 
dan pendidikan khususnya Islam supaya dapat diterima masyarakat. Metode mau'izhah hasanah, metode al-hikmah, metode tadarruj atau tarbiyatul ummah, metode kaderisasi, metode syura (musyawarah) merupakan metode yang sudah dilaksanakan sunan Gunung Jati.

\section{Relevansi Nilai-nilai Ajaran Sunan Gunung Jati dengan Pendidikan Islam}

Konsep petatah petitih dari Sunan Gunung Jati apabila dikaitkan dengan kondisi modern seperti ini masih mempunyai keterkaitan yang erat. Sistem pendidikan saat ini masih membutuhkan nilai- nilai dari pendidikan agama yang mampu menjadi panduan dan benteng dari gempuran kondisi masyarakat dunia yang semakin kompetitif. Nilai-nilai relijiusitas dan moralitas menjadi hal penting yang perlu di berikan kepada generasi sekang dan selanjutnya.

Nilai ketauhidan yang menjadi dasar utama dalam pendidikan islam perlu mendapatkan porsi yang lebih. Hal ini sejalan dengan konsep petatah petitih sunan gunung jati yaitu Insun titip tajug lan fakir miskin. Keimanan menjadi nilai mutlak yang wajib dimiliki masyarakat. Keimanan seseorang terbentuk dari pelaksanaan ibadah yang baik. Oleh sunan gunung jati dianalogikan dengan Tajug (musholla). Tajug merupakan simbol nilai pendidikan Islam dalam menyeimbangkan kehidupan dunia dan akhirat.

Nilai pendidikan Islam yang tercakup dalam petatah-petitih Ingsun titip tajug Ian fakir miskin adalah tentang nilai ketuhanan, nilai akhlak atau moral, nilai ketawaduan, dan nilai ketakwaan. Nilai keimanan dalam ajaran islam juga selalu berkaitan dengan amal soleh. Keberadaan manusia sama sebagai makhluk ciptaan Allah untuk beribadah dan menyembahnya.

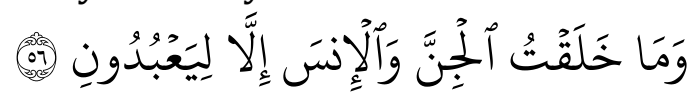

Dan Aku tidak menciptakan jin dan manusia kecuali supaya mereka mengabdi kepada-Ku (QS. Al Dzariyyat: 56).
Makna dari ayat di atas adalah manusi mempunyai kedudukan yang sama. Tidak ada seorang pun manusia yang berhak merendahkan orang lain, apalagi ingin menguasainya (Nawawi, 1992 : 155).

Petatah petitih kedua yang berhubungan dengan ibadah solat di gambarkan dalam kiasan Yen sembahyang kungsi tertaling gundewa. apabila shalat, harus khusyuk dan tawadhu' diibaratkan seperti anak panah yang menancap kuat. Shalat merupakan salah satu rukun diantara lima rukun Islam, yaitu mengucap syahadat, shalat, puasa, zakat dan haji bila mampu (Zurinal dan Aminuddin, 2008 :64). Solat dapat mengajarkan tentang pengendalian emosi dan ketenangan jiwa. Konsep ini penting sekali diajarkan kepada anak didik disekolah bahwa ibadah solat khususnya merupakan pendidikan dalam menumbuhkan perilaku yang baik. Sholat dapat membersihkan hati dan akal pikiran. Sholat juga dapat mencegah perbuatan keji dan mungkar. Sesuai dengan QS Al-Ankabut ayat 45:

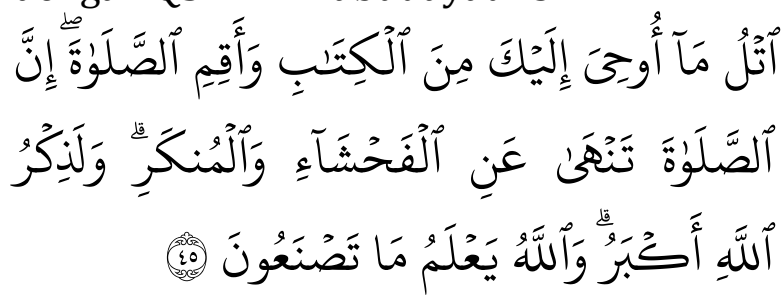

"Bacalah apa yang telah diwahyukan kepadamu, yaitu Al Kitab (Al Quran) dan dirikanlah shalat. Sesungguhnya shalat itu mencegah dari (perbuatan-perbuatan) keji dan mungkar. Dan sesungguhnya mengingat Allah (shalat) adalah lebih besar (keutamaannya dari ibadat-ibadat yang lain). Dan Allah mengetahui apa yang kamu kerjakan".

Shalat punya nilai filosofi yang sangat dalam bagi umat Islam. Kebenaran bukan sesuatu yang mudah diperoleh, sehingga setiap saat harus dimohonkan kepada Tuhan. Maksudnya dari ini adalah manusia harus mempunyai sikap rendah hati. Jika seseorang memohon petunjuk kepada Allah, ia harus membersihkan diri 
dari pengakuan kalau ia sudah tahu (Madjid, 2003:117).

Ajaran petatah petitih sunan Gunung jati yang ketiga yaitu tentang melatih puasa. Yen puasa den kungsi tetaling gandewa (jika puasa harus kuat seperti tali anak panah). Puasa, selain mempunyai nilai kesalehan individu, juga mempunyai nilai sosial. Orang yang berpuasa akan bisa merasakan bagaimana penderitaan yang dirasakan oleh orang yang secara ekonomi tidak mencukupi.

Nilai ajaran Islam yang didapatkan dari ungkapan ini yen puasa den kungsi tetaling gundewa adalah dengan puasa dapat mendidik manusia menjadi pribadi muslim yang bertaqwa, dengan adanya puasa dapat menjadi sarana pendidikan akhlak maksud dari sarana pendidikan akhlak disini yaitu mendidik manusia untuk berkikap jujur dan amanah, bisa mendidik manusia untuk bisa hidup sederhana, bisa bersifat sabar dan bisa mengendalikan hawa nafsu (Ramayulis, 2008:166).

Pengendalian hawa nafsu sangat penting saat ini untuk menghadapi persoalan jaman. Banyak kasus yang terjadi karena tidak mampunya seseorang mengelola hawa nafsunya. Perilaku agresif baik verbal atau fisik, perilaku korupsi, perilaku bullying dan lainnya merupakan contoh nyata. Salam pendidikan agama puasa menjadi satu cara untuka mengendalikan masalah ini.

Konsep istiqomah yang terkandung dalam petatah petitih Ibadah kang tetap (ibadah harus terus-menerus) juga mempunyai relevansi dalam kehidupan modern saat ini. Kehidupan adalah suatu misteri yang harus dipecahkan oleh manusia, dan tidak satu pun manusia di dunia ini nir persoalan. Ibadah merupakan cara kita mendekatkan diri kepada Allah dan untuk membuat batin manusia menjadi stabil. Sunan Gunung Jati menekankan agar selalu konsisten dalam beribadah.

Selanjutnya petatah petitih Wedi ing Allah (takutlah kepada Allah). Sikap ini, menurut Sunan Gunung Jati, merupakan sikap penting dan mutlak dimiliki setiap orang.

Ketakutan terhadap Allah sebetulnya merupakan pembebasan manusia dari rasa kekhawatiran dan ketakutan terhadap sesama manusia. Pengalaman telah menunjukkan, jika pemimpin negara tidak mempunyai rasa takut kepada Allah, ia akan takut terhadap manusia (Eman Suryaman, 2015:108).

Ketakutan kepada Allah ini sebagai kontrol manusia dalam upaya selalu melakukan hal yang baik dan menjauhi larangan yang di perintahkan Allah.

Manah den syukur lan Allah mempunyai arti hati yang harus selalu bersyukur pada Allah adalah petatah petitih dari ajaran sunan gunung jati selanjutnya. Syukur adalah menerima apa yang sudah dilimpahkan nikmat dari Allah SWT yang diberikan kepada kita. Baik dengan cara menyebut atau dengan cara menggunakan apa yang sudah diberikan dengan sebaik-baiknya dan dipergunakan di jalan yang dikehendaki oleh Allah.

Rasa Syukur akan mengajarkan manusia untuk tidak melakukan hal - hal yang dilarang karena munculnya sifat rakus dan tamak. Syukur akan mengajarkan manusia menerima sesuai kebutuhan bukan karena keinginan.

Point terakhir dari ajaran petatah petitih adalah Kudu ngahekaken pertobat (Banyak-banyaklah bertaubat). Taubat adalah bentuk kepasrahan manusia setelah melakukan dosa atau kesalahan. Menyesalinya dan berkeinginan kuat untuk tidak mengulangi kesalahan. Taubat adalah meninggalkan dosa yang selama ini sudah diperbuat karena Allah Swt, dengan perasaan menyesal, atas perbuatan maksiat yang selama ini diperbuat bertekad kuat untuk tidak mengulanginya dan selalu menaati perintah-Nya (Ibn Qayyim Aljauziah, 1998: 35)

Taubat adalah bentuk evaluasi dan kepasrahan diri setelah melakukan perbuatan. Taubat akan mempunyai makna menjadikan manusia selalu memperbaiki diri dari kesalahan yang sudah diperbuat. Taubat juga 
mencerminkan kelapangan hati untuk meminta maaf. Nilai ini sangat penting diajarkan kepada anak didik supaya mereka mempunyai keberanian mengakui kesalahan, baik kesalahan terhadap teman, orang tua, guru atau yang lainnya. Berdasarkan analisa dan pembahasan di atas, kesimpulan yang diperolah adalah bahwa ajaran sunan Gunung jati dalam konsep petatah petitih masih sangat relevan dalam pendidikan agama di masa sekarang. Nilai - nilai ini sangat sesuai dengan penanaman nilai nilai dalam pendidikan karakter dan kepribadian siswa.

\section{PENUTUP}

Penelitian ini menunjukkan bahwa konsep petatah-petitih Sunan Gunung Jati dibagi 4 bidang yaitu tentang ketakwaan dan keimanan, kedisiplinan, kearifan dan kebijaksanaan, dan kesopanan atau etika. Kajian dalam penelitian ini khusus tentang ketakwaan dan keimanan. Dalam ketakwaan dan keimanan terdapat beberapa isi yaitu sebagai berikut: Ingsun titipna tajug lan fakir miskin, yen sembah yang kungsi pucuke panah, yen puasa den kungsi tetaling gundewa, ibadah kang tetep, wedia ing Allah, manah den syukur ing Allah dan kudu ngahekaken pertobat.

Nilai-nilai keimanan dan ketakwaan yang disampaikan oleh Sunan Gunung Jati yaitu menekankan terhadap masalah ibadah, khususnya hubungan manusia kepada Tuhannya, menemukan dasar sifat moral Islam. Moral Islam menjelaskan bahwa kebahagiaan yang dicapai oleh manusia bukan saja untuk kehidupan dunia, melainkan juga untuk kehidupan akhirat.[]

\section{DAFTAR RUJUKAN}

Abu, Ahmadi. \& Noor Salimi, Dasar-dasar Pendidikan Agama Islam, Jakarta: Bumi Aksara, 2008.

Aljauziah, Ibn Qayyin Majaridus Salikin (Pedakian Menuju Allah) terjemahan Kathur Surhardi cet. 1, Jakarta: Pustaka Al-Khausat, 1998.
Atja. Tjarita Purwaka Tjaruban Nagari, Seri Monografi No. 5, Jakarta: Ikatan Karyawan Museum, 1986.

Azizi. Abdul Filsafat Pendidikan Islam Sebagai Gagasan Membangun Pendidikan Islam, Yogyakarta: Teras, 2009.

Daradjat, Zakiah. Dasar-dasar Agama Islam, Jakarta: Bulan Bintang, 1992.

Ekadjati. Sunan Gunung Jati dan Pengembangan Islam di Daerah Cirebon. Cirebon: Laporan Penataran Filosogi, 1974.

Gottschalk, Louis. Mengerti Sejarah. Terjemahan. Nugroho Notosusanto, Jakarta: UI Press, 1986.

Hardi. Titan Rokhmutiana dan Rohman, M. Nur, Dakwah Sunan Gunung Jati Dalam Proses Islamisasi Di Kesultanan Cirebon Tahun 14791568. (2014): Jurnal Prodi Pendidikan Sejarah Universitas Negeri Yogyakarta,1-9.

Husna, Aura (Neti Suriana). Kaya dengan Bersyukur: Menemukan Makna Sejati Bahagia dan Sejahtera dengan Mensyukuri Nikmat Allah, Jakarta: PT. Gramedia Pustaka Utama, 2013.

Irawan, Prasetyo. Metode Penelitian Jakarta: Universitas terbuka, 2009.

Kementerian Agama Republik Indonesia. Al-Qur'anul Karim dan Terjemah. Surakarta: Az-Ziyadah, 2014.

Kistoro, Hanif Cahyo Adi. Kecerdasan Emosional dalam Pendidikan Islam,"Jurnal Pendidikan Agama Islam". XI.1 (2014): 1-18.

Kurnia, Dadang. "Metode Da'wah Sunan Gunung Jati (Suatu Tinjauan dari Sudut Antropologi Pendidikan)", Jurnal Pendidikan Dasar, Volume V, No.7, (2007): 1-4.

Madjid. Pesan-Pesan Takwa, Jakarta: Paramadina, 2003.

Mahmud. Metode Penelitian Pendidikan. Bandung: CV Pustaka Setia, 2011.

Nawawi. Kepemimpinan yang Efektif, Yogyakarta: Gadjah Mada University Perss, 1992. 
Prawiraredja. Cirebon Falsafah Tradisi dan Adat Budaya. Jakarta: Perum Percetakan Negara RI, 2005.

Ramayulis. Ilmu Pendidikan Islam, Cet-6, Jakarta: Kalam Mulia, 2008.

Saksono. Mengislamkan Tanah Jawa; Telaah Atas Metode Dakwah Walisongo, Bandung: Mizan, 1995

Sjamsuddin. Helius Metodologi Sejarah, Yogyakarta: Ombak, 2012.

Sugiyono. Metode Penelitian Pendidikan, Bandung: Alfabeta, 2012.

Sulendraningrat, P.S., Sejarah Cirebon, Jakarta: Departemen Pendidikan dan Kebudayaan, 1978.

Sunardjo. Meninjau Sepintas Panggung Sejarah Pemerintahan Kerajaan Cerbon 1479-1809, Bandung: Tarsito, 1983.

Suryaman. Eman Jalan Hidup Sunan Gunung Jati, Bandung: Nuansa Cendekia, 2015.

Susanto. Musyrifah, 2012. Sejarah Peradaban Islam Indonesia, Jakarta: Rajawali Pers.

Wildan. Sunan Gunung Jati Antara Fiksi dan Fakta; Pembumian Islam dengan Pendekatan Struktural dan Kultural. Bandung: Humaniora, 2002.

Wildan. Sunan Gunung Jati Antara Fiksi dan Fakta; Pembumian Islam dengan Pendekatan Struktural dan Kultural. Bandung: Humaniora, 2002.

Zuhdi. Susanto, Cirebon Sebagai Bandar Jalur Sutra (Kumpulan Makalah Diskusi Ilmuah). Jakarta: CV. Putra Sejati Raja, 1997.

Zurinal. dan Aminuddin. Fiqih Ibadah, Jakarta: Lembaga Penelitian UIN, 2008. 